353

レーザ蛍光法による超音速矩形衝突噴流自励振動サイクルの可視化

（九州大学）村石 隆、大野 和彦(院)○、馬場隆太郎(院) 井上 雅弘、益田 光治、古川 雅人

\title{
Visualization of Self-Sustained Oscillation in an Impinging Supersonic Rectangular Jet by LIF
}

Takashi Muraishi Kazuhiko Ohno Ryuutarou Baba Masahiro Inoue Mituharu Masuda Masato Furukawa

Abstract: Feedback mechanism of self-sustained oscillation in supersonic impinging jets is studied experimentally by using a laser-induced fluorescence (LIF) technique. Phase velocities of disturbances in the flow field are obtained from a time-dependent cross-correlation function between a pressure sensor signal at a reference point and the LIF signal. A feature of disturbance propagation can be visualized by drawing maps for the cross-correlation coefficients on a plane at successive delay-times and making an animation. The discrete frequencies appeared near the neutral wave frequencies proposed by Tam and symmetric and asymmetric modes of the neutral wave were observed corresponding to his theory.

Key words: laser-induced fluorescence, supersonic jet, impinging jet, oscillation

1. 序論

ノズルから高速で放出する噴流が、ノズル直径 の数倍の距離に位置する平板に垂直に衝突すると、 フィードバックループを伴う自励振動により衝突 音(impingement tone)と呼ばれる離散周波数を持った ノイズが放射される[1-2]。

先に著者らは、LIF法と圧カセンサを併用して高 速気流中の温度変動の位相速度を計測する実験解 析手法を用いて相互相関係数の位相変化により渦 の挙動やフィードバック波の伝播経路を調查し、 出ロマッハ数 $\mathrm{M}=1.31$ の高速円形衝突噴流における 自励振動サイクル形成メカニズムを明らかにした [4]。そこで、本研究では同じ手法を用いて出ロマ ッハ数 $\mathrm{M}=1.51$ の超音速矩形衝突噴流における自励 振動サイクル形成メカニズムの検討を行った。

\section{2. 実験装置及び実験方法}

本実験においてはFig.1に示すようなスロート幅 $6 \mathrm{~mm}$ 、出口幅 $\mathrm{H}=8 \mathrm{~mm}$ の矩形断面ラバルノズルを用 いた。ノズル全域で奥行き幅は $10 \mathrm{~mm}$ となっている。 そのノズルを使用してノズル出ロマッハ数 $\mathrm{M}=1.51$ の適正膨張噴流を平板に垂直に放出させた。噴流 を衝突させる平板は一辺 $120 \mathrm{~mm}$ 四方の正方形であ る。またノズルと平板の距離と Lとし、 $\mathrm{L} / \mathrm{H}=1 \sim 10$ $(\mathrm{L}=8 \sim 80 \mathrm{~mm})$ の範囲で実験を行った。

実験装置は過去の研究[4]で用いたものと同じで あり、吸い込み式風洞により発生させた超音速流 れにヨウ素を混入し、アルゴンイオンレーザーを 用いたLIF法により可視化している(本実験条件に おいては蛍光強度は流れ場の温度のみの関数とな る[5])。

自励振動周波数測定は、衝突平板上において噴 流の中心部から $6.6 \mathrm{~mm}$ の位置に設置した圧力セン サにより行った。平板はステッピングモータによ る移動装置に直結されており、 $\mathrm{L}=8 \sim 80 \mathrm{~mm}(\mathrm{~L} / \mathrm{H}=1 \sim 10)$ を $0.25 \mathrm{~mm}$ 単位で調節し、 $\mathrm{L} / \mathrm{H}$ の
微小変化ことに平板上の圧カセンサの信号を周波
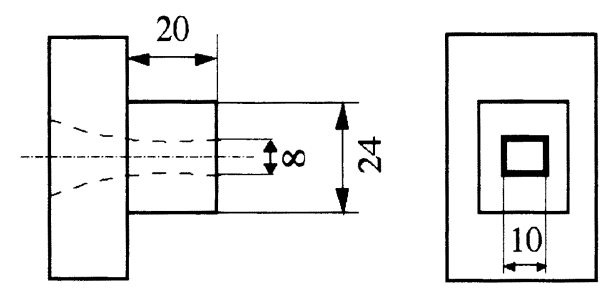

Fig.1 Nozzle configuration

数解析した。

相互相関測定における測定部の詳細図をFig.2に 示す。座標系は、ノズル出口断面における噴流の 中心部分を原点とし、原点より流れ方向にX軸、 手前方向にY軸、垂直方向にZ軸をとった。XZ、 YZの各断面に $1 \mathrm{~mm}$ 単位でメッシュを切って測定点 とし、LIF法による各測定点での蛍光強度変動と基 準となる圧力変動を同時に取得した。卓越周波数 の前後 $1 \mathrm{kHz} に$ バンドパスフィルタをかけて相互相 関係数を求め、同一遅れ時間こととに測定メッシュ に準じてプロットすれば、自励振動により生じる 特定の周波数成分を持った擾乱の伝播挙動を動画 により観察できる。なおこの測定においては、ヨ ウ素による腐食の防止と平板への光学ガラス埋設 の必要性から、圧力センサ位置は噴流の中心部か ら $40 \mathrm{~mm}$ 上方とした。

\section{3. 実験結果及び考察}

自励振動周波数測定結果をFig.3に示す。この図 では、縦軸に周波数 $\mathrm{f}[\mathrm{kHz}$ 、横軸は $\mathrm{L} / \mathrm{H}$ とった平 面上にスペクトル密度(PSD)の等高線を階調スケー ルで示すことにより、卓越周波数の存在を示して いる。なお、四の右側には周波数をノズル出口直 径とノズル出口流速で無次元化したストロハル数 $\mathrm{St}=\mathrm{fH} / \mathrm{U}$ 記している。

自励振動周波数はフィードバックループ上に存 在する擾乱の数が同一であれば、ノズル出口〜平 板間の距離Lの増加に伴い減少するが、自励振動 
の起こりやすい周波数帯が存在するため、L/Hの 増加に伴い周波数がその周波数帯の下端に達する と、擾乱の数が不意に増加して周波数が高い值へ ジャンプすると考えられている。Fig.3において $13 \mathrm{kHz} 、 16 \mathrm{kHz} 、 23 \mathrm{kHz}$ 付近において鋸歯状の周波数 分布がみられるのはこのためである。周波数帯が 限られる理由として、Tamら [3]は一様流れと仮定 した噴流に微小擾乱を重ねた線形理論解析によっ て噴流内外に分散しにくい波数を持つ、噴流固有 のニュートラル波が複数あることを示し、このニ ユートラル波が上流に伝播するフィードバックに 関係するからであると述べている。先の著者らの 研究 [4]により、Tamらの理論解析は円形噴流にお いては非常に良い一致を見せており、自励振動周 波数やそのメカニズムの予測に非常に有効である ことが示されている。彼らの2次元噴流に対する 理論計算によると、 $\mathrm{M}=1.51$ における幅方向モード 1非対称ニュートラル波の平均ストロハル数は 0.16 〜 0.27であり、これは $13 \mathrm{kHz}$ 付近の周波数帯を含む 範囲である。また $\mathrm{M}=1.29$ における幅方向モード 2 対 称ニュートラル波の平均ストロハル数は $0.42 \sim 0.49$ であり、 $23 \mathrm{kHz}$ 付近の周波数帯と非常に近い值で ある。このことからこれら2つの周波数帯の自励 振動はそれぞれのニュートラル波に対応している と考えられる。しかし、16kHz付近の周波数帯に は、対応するストロハル数のニュートラル波が存 在しなかった。このことから、この周波数帯の自 励振動は他の $2 \supset$ 周波数帯の自励振動とは異な るメカニズムをもっている考えられる。そこで、 これらの周波数帯における自励振動サイクルを解 明するため、Fig.3に矢印で示す3地点において擾乱 の伝播形態を調べた。

Fig.4には、L/H=2.88、f=12.4kHzにおける擾乱の伝 播形態を観察するために圧力変動と温度変動の相 互相関係数の時間変化を示している。相互相関係 数は正負が逆位相で交互に現れるため、正の值の みを階調表示することで簡素化してある。

まずどの図においても、噴流中心軸に対して上 下の剪断層を対流する渦が交互に現れており、渦 構造が非対称であるとが分かる。また (d) ( f $)$ にお いてフィードバック波が見られるが、噴流外を遡 る擾乱に加えて噴流内を同期して遡る擾乱が確認 できる。しかし、主流が超音速であることや、円 形超音速噴流においては噴流外の擾乱がフィード バックメカニズムの主な役割を担っていたことか ら、矩形噴流においても噴流外の擾乱によるフィー ドバックメカニズムが支配的であると考えられる。 (f) (h)においてフィードバック波によって $z=4 \mathrm{~mm} の$ 剪断層が刺激され、 $\mathrm{x}=5 \mathrm{~mm}$ 付近に渦が誘起されて いる（(h)）。一方、 $z=-4 \mathrm{~mm}$ 付近の剪断層について は(a) (d)において刺激され、(d)の $\mathrm{x}=5 \mathrm{~mm}$ 付近に渦が

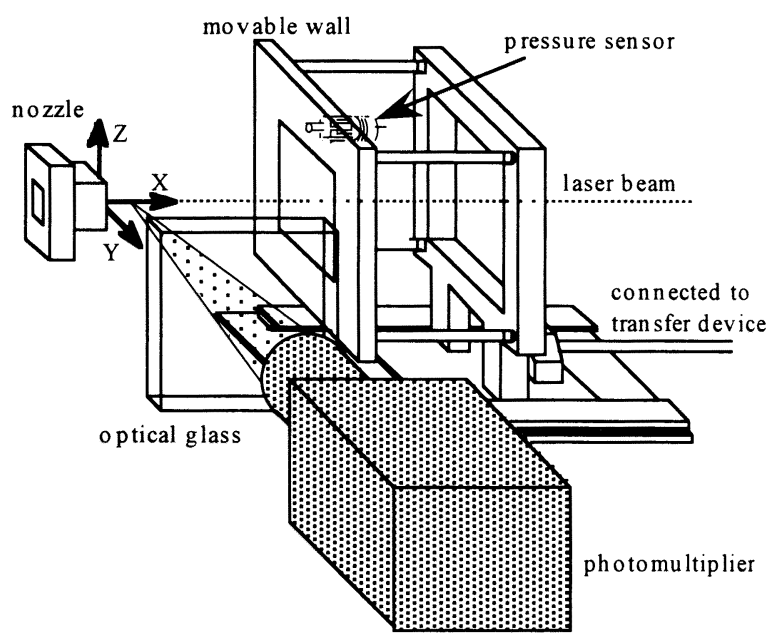

Fig.2 Detail of experimental setup for cross-correlation measurement

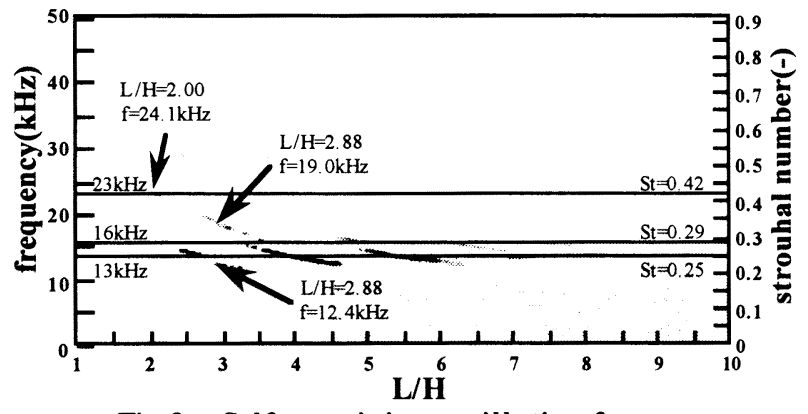

Fig.3 Self-sustaining oscillation frequency as a function of $\mathrm{L} / \mathrm{H}$

誘起される。以降同様の剪断層への刺激が交互に 繰り返され、位相差を持った渦が下流に対流して いく。下流へ対流した渦はそれそれ平板に衝突し、 ウォールジェット成分へ推移する。その後、フィー ドバック波が発生し、ノズル出ロへと伝播してい く。

このように、フィードバック波は噴流中心軸に 対して交互に現れており、非対称性を有している ことが分かった。

次に $\mathrm{L} / \mathrm{H}=2.88 、 \mathrm{f}=19.0 \mathrm{kHz}$ における擾乱の伝播形態 を動画で観察する（Fig.5）。(b) (d)において、噴 流の外側からノズル出口部分に向かう擾乱により 剪断層が刺激を受けて渦が発生し、剪断層に沿っ て下流へと伝播していく。(e)では $\mathrm{x}=7 \mathrm{~mm} 、 Z= \pm$ $4 \mathrm{~mm}$ の部分で相関值が高く、発生した渦は対称性 を持っていると思われる。その渦は、噴流外を遡 るフィードバック波と干涉した後（(a)）、噴流内 を遡るフィードバック波と干涉し $\mathrm{x}=7 \mathrm{~mm}$ 付近の噴 流内に相関の高い領域を形成する（(b)）。以降、 渦は噴流内外を遡るフィードバック波と交互に干 渉を繰り返しながら伝播を続け（(b) (d)）、平板 に衝突する（(e)）。そこでウォールジェット成分 への推移を経た後、平板に沿って外側へと伝播し ていく過程 $((\mathrm{a}) \sim(\mathrm{b}))$ で、噴流外にフィードバック波 
が発生している（(c)）。そのフィードバック波は 下流へ対流する渦と干涉を続け、噴流外を上流へ 伝播し続けることでノズル出口に達し((c) (e) (b))、 剪断層を刺激することで新たな渦を誘発する((c) )。 また、(c)から $12 \mathrm{~ms}$ 遅れた (d)において、 $\mathrm{x}=15 \mathrm{~mm} の$ 噴 流内部にフィードバック波が発生している。こち らは噴流内を伝播してノズル出口に達しても、剪 断層を刺激して新たな渦を誘発することはないよ うである。

上述のようにフィードバック波は噴流内外に存 在し、それらは位相差を持って交互に上流に向か って伝播していることが分かった。

Fig.6には、L/H=2.00、f=24.1kHzにおける擾乱の伝 播形態を示している。全ての図から、剪断層部を 伝播する渦は噴流中心に対して対称であることが 分かる。(a) (b)にかけて剪断層付近の噴流内外に 存在するフィードバック波がノズル出口に向かっ て伝播し、(c)において $\mathrm{z}= \pm 4 \mathrm{~mm}$ 付近に渦が発生す る。渦は剪断層に沿って下流へと伝播していき ( (d)）、やがて剪断層付近を遡ってきたフィード バック波と干涉する（(e)）。渦は更に伝播を続け ( (a) (b)) 、再びフィードバック波と干涉した後、 更に下流へと対流して、平板に衝突する $((\mathrm{c}))$ 。 イードバック波は剪断層付近の噴流内外に同時に 発生し、ノズル出口に向かって伝播する $((\mathrm{d}))$ 。ま た(a) (b)に注目すると、剪断層周辺を遡るフィー ドバック波に加えて、噴流中を位相差を持って上 流へ遡るフィードバック波が確認できる。この擾
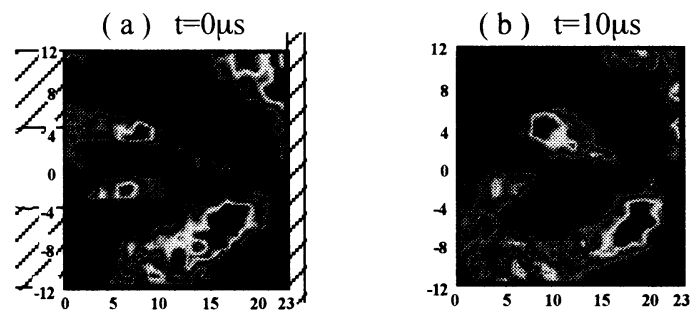

(e ) $\mathrm{t}=40 \mu \mathrm{s}$

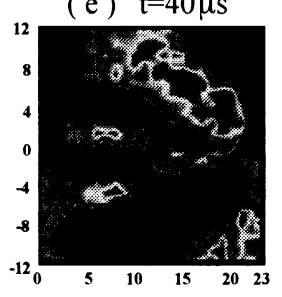

(f) $\mathrm{t}=50 \mu \mathrm{s}$

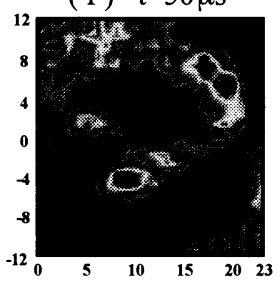

乱はノズル出口に達しても、剪断層を刺激して新 たな渦を誘発することはないようである。

以上のことからフィードバック波は剪断層付近 と噴流中心に存在し、それらは位相差を持って交 互に上流に向かって伝播していることが分かった。 また、この擾乱の挙動はFig.6に示したものと非常 に近いものであった。

Fig.5と Fig.6に示した擾乱の伝播形態は非常に近 いものであった。これらの違いをYZ断面の相関マ ップを用いて検討した。Fig.7は $\mathrm{L} / \mathrm{H}=2.88 \cdot \mathrm{f}=19.0 \mathrm{kHz}$ の自励振動と、 $\mathrm{L} / \mathrm{H}=2.00 \cdot \mathrm{f}=24.1 \mathrm{kHz}$ の自励振動のあ る遅れ時間における平板付近のYZ断面相関マップ である。これによると $\mathrm{L} / \mathrm{H}=2.88 \cdot \mathrm{f}=19.0 \mathrm{kHz}$ 自励振 動の方の相関マップではほぼ同心円状に高相関領 域が分布しており、ウォールジェットはほぼ円形 であることが分かった。一方、 $\mathrm{L} / \mathrm{H}=2.00$ ・ $\mathrm{f}=24.1 \mathrm{kHz}$ の自励振動においては $z= \pm 4 \mathrm{~mm}$ 付近に高 い相関領域が存在し、ウォールジェットは軸方 向に強い二次元性を有していることが確認された。

以上のことから、対応するニュートラル波が存 在しなかった $\mathrm{L} / \mathrm{H}=2.88 \cdot \mathrm{f}=19.0 \mathrm{kHz}$ 自励振動は、矩 形噴流でありながら軸対称性の強い振動モード有 していることが分かった。

\section{4. 結論}

LIF法と圧力センサを併用した非定常計測システ ムにより、 $\mathrm{M}=1.51$ の超音速矩形衝突噴流における 自励振動サイクルの解明を行った。その結果、自

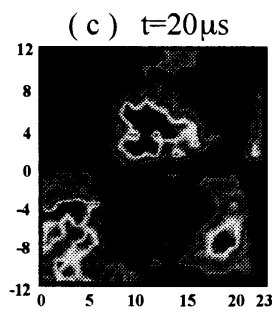

( g ) $\mathrm{t}=60 \mu \mathrm{s}$

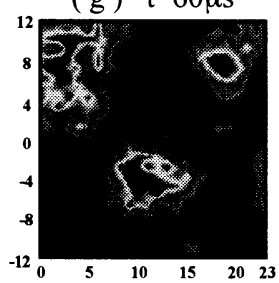

(d) $\mathrm{t}=30 \mu \mathrm{s}$

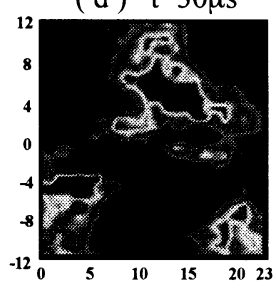

(h) $\mathrm{t}=70 \mu \mathrm{s}$

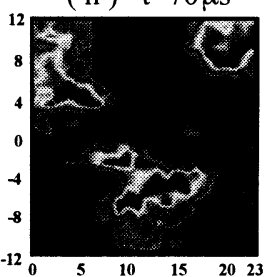

Fig.4 Propagation of disturbances $(\mathrm{L} / \mathrm{H}=\mathbf{2 . 8 8}, \mathrm{f}=\mathbf{1 2 . 4 \mathrm { kHz }})$
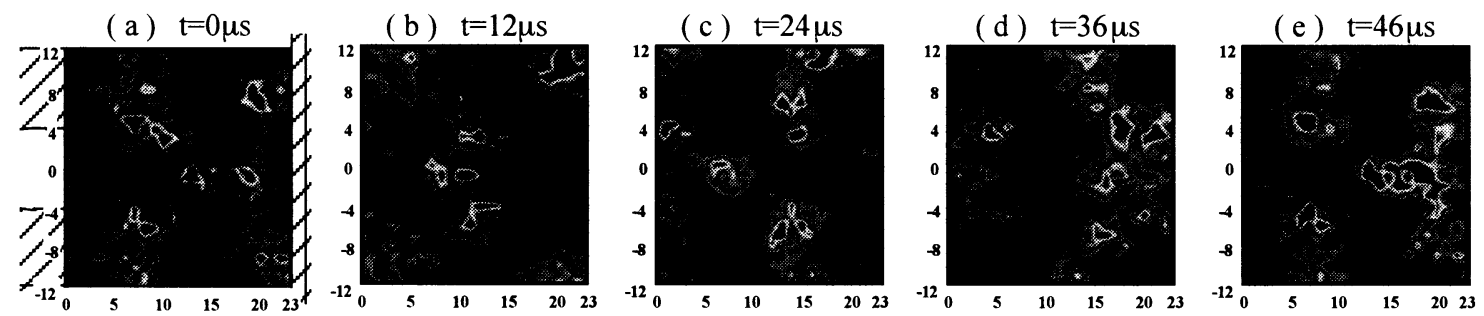

Fig.5 Propagation of disturbances $(\mathrm{L} / \mathrm{H}=2.88, \mathrm{f}=19.0 \mathrm{kHz})$ 
励振動はTamらの提唱するニュートラル波に対応 した振動周波数を持つことが分かった。それらの 自励振動メカニズムにおいて、フィードバック波 は噴流外だけではなく噴流内にもに存在し得るが、 主に外側からのフィードバックの方が支配的であ った。また、ニュートラル波に対応しなかった $\mathrm{f}=19.0 \mathrm{kHz}$ の自励振動は、三次元性の強いフィード バックメカニズムを持つことが分かった。

参考文献

[1] Wagner, F. R., NASA Technical Translation, F-13,942, 1971.

[2] Neuwerth, G., NASA Technical Translation, F-15,719, 1974.

[3] Tam, C. K. W. \& Norum. T. D., AIAA Journal, Vol.30, No.2 February 1992, pp.304-311

[4] 井上ほか 5名, 可視化情報, Vol.20, Supple., No.1, pp.487-490.

[5] Inoue, et al., FED-Vol.218, Experimental and Numerical Flow Visualization, ASME, 1995.

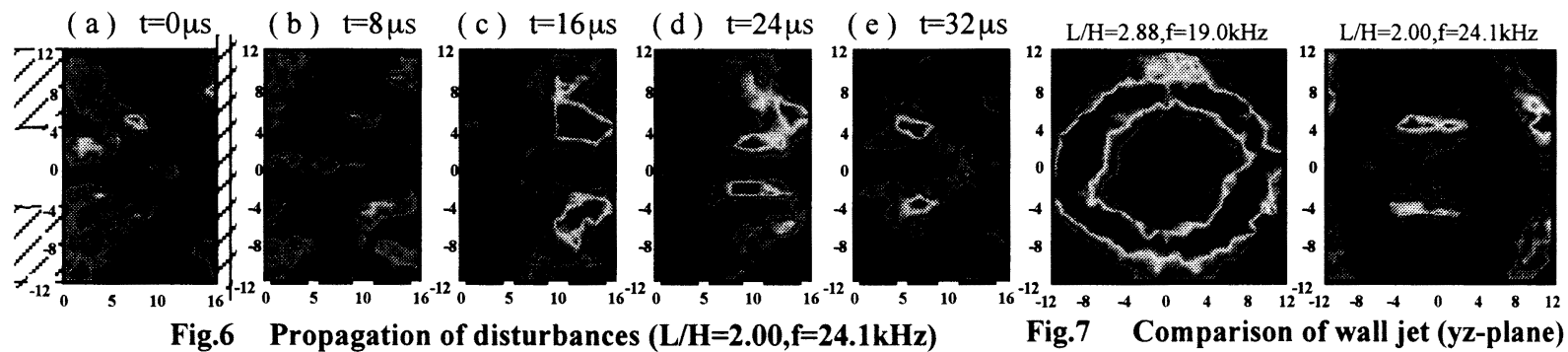

